\title{
PECULIARITIES OF INSULIN RESISTANCE SYNDROME IN NON-ALCOHOLIC STEATOGEPATITIS ON THE BACKGROUND OF TYPE 2 DIABETES MELLITUS DEPENDING ON THE STAGE OF DIABETIC KIDNEY DISEASE
}

\author{
O.S. Khukhlina ${ }^{1}$, Z. Ya. Kotsiubiichuk ${ }^{1,2}$
}

${ }^{1}$ Higher State Educational Institution of Ukraine "Bukovinian State Medical University", Chernivtsi, Ukraine; ${ }^{2}$ Regional Municipal Non-Profit Enterprise "Chernivtsi Emergency Hospital”, Chernivtsi, Ukraine

\begin{tabular}{l}
\hline \hline Key words: non-alcoholic \\
steatohepatitis, type 2 \\
diabetes mellitus, diabetic \\
kidney disease, insulin \\
resistance. \\
Bukovinian Medical Herald. \\
2020. V.24, № 3 (95). P. 134- \\
142. \\
DOI: \\
10.24061/2413-0737. \\
XXIV.3.95.2020.84
\end{tabular}

E-mail:

oksanakhukhlina@gmail.com, zoryana19_gr8@bigmir.net

\begin{abstract}
Objective. To study the interaction of changes in glucose and insulin homeostasis, the degree of $I R$ and insulin sensitivity, the degree of glycosylation of hemoglobin on the clinical course of NASH on the background of diabetes mellitus depending on the presence of DKD and its stage.
\end{abstract}

Material and methods. 108 patients with NASH with comorbid diabetes were examined. The average age of patients was $(58.2 \pm 6.1)$ years. There were 63 women (58.3\%) and 45 men (41.7\%). Depending on the presence of DKD, 4 groups of patients were formed, which were randomized by age, sex, activity of cytolytic syndrome of NASH depending on the stage of DKD. The comparison group consisted of 30 healthy individuals (PHP) of the appropriate age and sex. The degree of hepatic steatosis and its nature were determined using a ratified kit "SteatoTest", "ASH" and "NASH-Test" (BioPredictive, France) in the laboratory Sinevo. The stage of liver fibrosis was determined by using a set of markers for quantitative biochemical evaluation of fibrosis "FibroTest" (BioPredictive, France) in the laboratory Sinevo. Calculation of the glomerular filtration rate (GFR) was performed using a GFR calculator of the Institute of Nephrology of the National Academy of Medical Sciences of Ukraine on the average of three calculated indicators: creatinine clearance according to the Cockcroft-Golt formula, MDRD and CKD EPI. Determination of the stages of DKD was carried out according to the classification of C.E. Mogensen (1983).

Results. In patients with NASH, diabetes mellitus and DKD I-II st. found a probable decrease in the content of albumin in the blood by $9.0 \%$ ( $p$ $<0.05)$, GFR and the content of albumin in the urine, on the contrary, probably increased 1.5 times $(p<0.05)$ compared with the indicator in PHP, which indicates the phenomenon of hyperfiltration and inherent in the initial stage of DKD. In patients with NASH, diabetes mellitus and DKD III found a probable decrease in the content of albumin in the blood by 1.2 times ( $p$ <0.05), GFR and albuminuria were significantly increased by 1.4 times and 11.7 times ( $p<0.05)$, respectively, compared with PHP. In patients with NASH, diabetes mellitus and DKD IV found a significant decrease in the content of albumin in the blood by 1.4 times ( $p$ $<0.05)$, the content of albumin in the blood was probably increased by 30.2 times $(p<0.05)$ compared with the indicator in the PHP, and the GFR - on the contrary, it was significantly reduced - 1.7 times ( $p<0.05)$, which indicates the progression of CKD and DKD.

Conclusions. Metabolic prerequisites for the development of nonalcoholic steatohepatitis on the background of type 2 diabetes mellitus are probable fasting and postprandial hyperglycemia, hyperinsulinemia, increased hemoglobin glycosylation, tissue insulin resistance compared to healthy individuals. Disorders of glucose homeostasis due to insulin resistance are one of the probable risk factors for the progression of 
Original research

nonalcoholic steatohepatitis and type 2 diabetes mellitus in the presence of stage I-IV diabetic kidney disease, as carbohydrate metabolism disorders and the degree of insulin resistance type 2 diabetes in the absence of diabetic kidney disease.

\begin{tabular}{l}
\hline \hline Ключові слова: \\
неалкогольний \\
стеатогепатит, иукровий \\
діабет типу 2, діабетична \\
хвороба нирок, \\
інсулінорезистентність.
\end{tabular}

Буковинський медичний вісник. 2020. T.24, № 3 (95), C. 134-142.

\section{ОСОБЛИВОСТІ СИНДРОМУ ІНСУЛІНОРЕЗИСТЕНТНОСТІ ПРИ НЕАЛКОГОЛЬНОМУ СТЕАТОГЕПАТИТІ НА ТЛІ ЦУКРОВОГО ДІАБЕТУ ТИПУ 2 ЗАЛЕЖНО ВІД СТАДІЇ ДІАБЕТИЧНОЇ ХВОРОБИ НИРОК}

\section{О.С. Хухліна, 3.Я. Коцюбійчук}

Мета роботи - вивчити взаємовплив змін гомеостазу глюкози та інсуліну, ступеня IP та чутливості до інсуліну, ступеня глікозилювання гемоглобіну на клінічний перебіг НАСГ на тлі ЦД2 залежно від наявності ДХН та ї̈ стадї.

Матеріал і методи. Обстежено 108 хворих на НАСГ із коморбідним ЦД2. Середній вік хворих $(58,2 \pm 6,1)$ років. Жінок було 63 (58,3\%), чоловіків - 45 (41,7\%). Залежно від наявності ДХН сформовано чотири групи пачієнтів, які були рандомізовані за віком, статтю, активністю цитолітичного синдрому НАСГ залежно від стадї ДХН. Групу порівняння склали 30 практично здорових осіб (ПЗО) відповідного віку та статі. Ступінь стеатозу печінки та його природу визначали за допомогою ратифікованого набору «SteatoTest», «ASH» ma «NASH-Test» (BioPredictive, Франція) у лабораторї Сінево. Стадію фіброзу печінки визначали иляхом використання набору маркерів для кількісної біохімічної оиінки фiброзу «FibroTest» (BioPredictive, Франція) у лабораторії Сінево. Обчислення показника швидкості клубочкової фільтрації (ШКФ) здійснювали за допомогою калькулятора ШКФ ДУ «Інституту нефрології НАМН Украӥни» за середньою величиною трьох обчислених показників: кліренсом креатиніну за формулою Кокрофта-Голта, MDRD та CKD EPI. Визначення стадій ДХН здійснювали за класифікаиією C.E. Mogensen (1983).

Результати. У хворих на НАСГ, ЦД2 та ДХН I-II cm. встановлено вірогідне зниження вмісту альбумінів у крові на 9,0\% $(p<0,05)$, ШКФ та вміст альбумінів у сечі, навпаки, вірогідно зросли в 1,5 раза $(p<0,05)$ порівняно з показником у ПЗО, що свідчить про явище гіперфільтрачії та притаманне початковим стадіям ДХН. У хворих на НАСГ, ЦД2 та ДХН III cm. встановлено вірогідне зниження вмісту альбумінів у крові в 1,2 раза $(p<0,05)$, ШКФ та рівень альбумінурії були вірогідно підвищені відповідно в 1,4 раза та 11,7 раза $(p<0,05)$ порівняно з показником у ПЗО. Ухворих на НАСГ, ЦД2 та ДХН IV cm. встановлено істотне зниження вмісту альбумінів у крові в 1,4 раза $(p<0,05)$, вміст альбумінів у крові був вірогідно підвищений у 30,2 раза $(p<0,05)$ порівняно з показником у ПЗО, а показник ШКФ - навпаки, був істотно зниженим - в 1,7 раза $(p<0,05)$, що вказує на прогресування ХХН та ДХН.

Висновок. Метаболічними передумовами розвитку неалкогольного стеатогепатиту на тлі иукрового діабету типу 2 є вірогідна натщесерцева та постпрандіальна гіперглікемія, гіперінсулінемія, зростання ступеня глікозилювання гемоглобіну, тканинна інсулінорезистентність порівняно зі здоровими особами. Розлади гомеостазу глюкози внаслідок інсулінорезистентності є одним із 
Оригінальні дослідження

вірогідних чинників ризику прогресування неалкогольного стеатогепатиту та тлі иукрового діабету типу 2 за наявності діабетичної хвороби нирок I-IV стадій, оскільки порушення вуглеводного обміну та ступінь інсулінорезистентності за иуих умов є суттєвіші порівняно з перебігом неалкогольного стеатогепатиту із иукровим діабетом типу 2 за відсутності діабетичної хвороби нирок.

\begin{tabular}{ll}
\hline \hline Ключевые слова: & ОСОБЕННОСТИ СИНДРОМА ИНСУЛИНОРЕЗИСТЕНТ- \\
неалкогольный & НОСТИ ПРИ НЕАЛКОГОЛЬНОМ СТЕАТОГЕПАТИТЕ НА \\
стеатогепатит, сахарный & ФОНЕ САХАРНОГО ДИАБЕТА ТИПА В В ЗАВИСИМОСТИ ОТ \\
диабет типа 2, & СТАДИИ ДИАБЕТИЧЕСКОЙ БОЛЕЗНИ ПОЧЕК
\end{tabular}

диабетическая болезнь почек, инсулинорезистентность.

Буковинский медицинский вестник. 2020. T.24, № 3 (95), C. 134-142.

\section{О.С. Хухлина, З.Я. Коцюбийчук}

Цель исследования - изучить взаимовлияние изменений гомеостаза глюкозы и инсулина, степени ИР и чувствительности к инсулину, степени гликозилирования гемоглобина на клиническое течение НАСГ на фоне СД2 в зависимости от наличия ДБП и ее стадии.

Материал и методы. Обследовано 108 больных НАСГ с коморбидным СД2. Средний возраст больных (58,2 \pm 6,1) года. Женшин было 63 (58,3\%), мужчин - 45 (41,7\%). В зависимости от наличия ДБП сформировано 4 группы пациентов, которые были рандомизированьл по возрасту, полу, активностью цитолитического синдрома НАСГ в зависимости от стадии ДБП. Группу сравнения составили 30 практически здоровых лич (ПЗЛ) соответствуюшего возраста и пола. Степень стеатоза печени и его природу определяли с помощью ратифицированного набора "SteatoTest», "ASH» $u$ «NASH-Test» (BioPredictive, Франичия) в лаборатории Синево. Стадию фиброза печени определяли путем использования набора маркеров для количественной биохимической оценки фиброза «FibroTest» (BioPredictive, Франция) в лаборатории Синево. Вычисление показателя скорости клубочковой фильтрачии (СКФ) осуществляли с помощьюю калькулятора СКФ ГУ «Институт нефрологии АМН Украинь»» по средней величине трех вычисленных показателей: КК по формуле Кокрофта-Голта, MDRD и CKD EPI. Определение стадий ДБП осуществляли по классификации C.E. Mogensen (1983).

Результаты. У больных НАСГ, СД2 и ДБП I-II cm. установлено достоверное снижение содержания альбуминов в крови на 9,0\% (p <0,05), СКФ и содержание альбуминов в моче, наоборот, достоверно возросли в 1,5 раза $(p<0,05)$ по сравнению $c$ показателем в УЗЛ, что свидетельствует о явлении гиперфильтрации и присуще начальным стадиям ДБП. У больных НАСГ, СД2 и ДБП ІІІ cm. установлено достоверное снижение содержания альбуминов в крови в 1,2 раза (p<0,05), СКФ и уровень альбуминурии были достоверно повышены соответственно в 1,4 раза и 11,7 раза ( $>$ <0,05) по сравнению с показателем в УЗЛ. У больных НАСГ, СД2 и ДБП IV cm. установлено существенное снижение содержания альбуминов в крови в 1,4 раза (p <0,05), содержание альбуминов в крови было достоверно повышено в 30,2 раза $(p<0,05)$ по сравнению с показателем в УЗЛ, а показатель СКФ - наоборот, был существенно сниженным - в 1,7 раза ( $p$ $<0,05)$, что указывает на прогрессирование ХБП и ДБП. 
Original research

Вывод. Метаболическими предпосылками развития неалкогольного стеатогепатита на фоне сахарного диабета типа 2 является вероятно тощаковая $u$ постпрандиальная гипергликемия, гиперинсулинемия, рост степени гликозилирования гемоглобина, тканевая инсулинорезистентность по сравнению со здоровыми лицами. Расстройства гомеостаза глюкозы вследствие инсулинорезистентности является одним из вероятных факторов риска прогрессирования неалкогольного стеатогепатита на фоне сахарного диабета типа 2 при наличии диабетической болезни почек I-IV стадий, поскольку нарушения углеводного обмена и степень инсулинорезистентности при этих условиях является более существенными по сравнению с течением неалкогольного стеатогепатита с сахарным диабетом типа 2 при отсутствии диабетической болезни почек.

Introduction. The article presents a theoretical generalization of the results of the study of insulin resistance syndrome (IR) in patients with non-alcoholic steatohepatitis (NASH) in comorbidity with type 2 diabetes mellitus (DM2) in the presence of diabetic kidney disease (DKD) and depending on its stage. It was found that disorders of glucose homeostasis due to IR is one of the significant risk factors for the progression of NASH and diabetes mellitus in the presence of DKD IIV centuries. insulin content - 2.9 times vs. 1.9 times, glycosylated hemoglobin - 2.3 vs. 1.6 times) and the degree of IR (increase in HOMA 3.4 times vs. 2.2 times) under these conditions are more significant in comparable with the course of NASH with diabetes mellitus in the absence of DKD ( $p<0,05)$. Indicators of postprandial and supracardial glycemia and insulinemia, as well as the degree of IR in patients with NASH and the background of diabetes mellitus2 with DKD IV. affect the increase in the intensity of cytolysis, cholestasis, mesenchymal inflammation, contribute to the development of hepatic steatosis, as well as renal dysfunction (GFR) ( $\mathrm{p}<0,05)$. The progression of DKD from stage I-II to stage IV on the background of diabetes mellitus2 and NASH depends on the level of hyperglycemia and the degree of IR $(p<0.05)$.

Relevance of research state of carbohydrate metabolism and the intensity of insulin resistance syndrome (IR) in the comorbid course of nonalcoholic steatohepatitis (NASH) and diabetic nephropathy (DN) in patients with type 2 diabetes mellitus (DM2) is due to the cascade of frequent reactions complications and possible transformation of NASH into liver cirrhosis [1, $2,3,4]$

Today, non-alcoholic steatosis of the liver and NASH are considered the most common liver pathology, which in developed countries is observed in $20-30 \%$ of the adult population $[5,1,6,7]$. It is proved that the most common cause of NASH is obesity and diabetes mellitus $2[8,9$, 10]. The combination of NASH and DM2 increases the risk of liver cirrhosis and hepatocellular carcinoma by 2 2.5 times $[2,11]$.

Diabetic nephropathy - a severe complication of diabetes is one of the leading causes of end-stage renal disease in industrialized countries [12, 13, 4, 14]. Since 2007, the National Foundation for Kidney Disease Initiative to Improve the Quality of Kidney Disease Treatment (K / DOQI) has proposed the use of the term "diabetic kidney disease" instead of "diabetic nephropathy" [12]. Diabetic kidney disease (DKD) or $\mathrm{DN}$ is a type of diffuse or focal glomerulosclerosis, Kimmelstil-Wilson syndrome [15, 14]. In addition, patients with diabetes often develop non-specific renal lesions such as asymptomatic bacteriuria, pyelonephritis, renal carbuncle, apostematous nephritis, renal abscess, renal tuberculosis, necrotic papillitis or papillary necrosis, which significantly aggravate the disease. DN is $40 \%$ of complications in diabetes mellitus1 and 5-15\% - among patients with diabetes mellitus 2 . On average, 20$30 \%$ of patients with diabetes of both types have DN, but among patients with diabetes mellitus much less often develops chronic renal failure on the background of DN $[12,13]$.

The main pathogenetic basis of NASH on the background of diabetes mellitus on the background of diabetes mellitus is a violation of the sensitivity of insulin receptors to membranes of insulin-sensitive organs (liver and skeletal muscle) to the hormone, disorders of transport and utilization of glucose from the circulatory system with the formation of all glycogen. species of metabolism in a healthy body $[1,2,6,11]$. It has been proved that in diabetes mellitus 2 the organism is rebuilt into an alternative energy supply - by catabolism of fat in visceral fat depots, as a result of which a significant amount of free fatty acids (FFA) enters the systemic circulation and is sent to the liver $[1,9,7]$. Due to significant inhibition of $\beta$-oxidation of FFA in hepatocytes in DM2, neutral fat in the form of triacylglycerols (TG) accumulates in hepatocytes and forms the pathomorphological basis of micro- or macrovesicular steatosis of the liver and, at the same time, deepens [16]. At the same time, the effect of DKD depending on its stage on the glycemic and insulin profile, the state of IR in NASH on the background of diabetes mellitus is still poorly understood, although 
disorders of glucose homeostasis may accelerate apoptosis of hepatocytes and podocytes, hyper- and dyslipidemia, early development and endothelial dysfunction, activation of inflammatory processes, fibrosing reactions in the liver and kidneys.

The aim of the study was to examine the interaction of changes in glucose and insulin homeostasis, the degree of IR and insulin sensitivity, the degree of glycosylation of hemoglobin on the clinical course of NASH on the background of diabetes mellitus depending on the presence of DKD and its stage.

Material and methods. 108 patients with NASH with comorbid diabetes mellitus 2 were examined. The average age of patients $(58.2 \pm 6.1)$ years. There were 63 women $(58.3 \%)$ and 45 men $(41.7 \%)$. Depending on the presence of DKD, 4 groups of patients were formed, which were randomized by age, sex, activity of cytolytic syndrome of NASH depending on the stage of DKD. The division into groups of examined patients is given in table. 1. The comparison group consisted of 30 practically healthy people (PHP) of the appropriate age and sex.

The diagnosis of NASH was established in accordance with the unified clinical protocol approved by the Order of the Ministry of Health of Ukraine № 826 of 06.11.2014, in the presence of criteria for exclusion of chronic diffuse liver disease of viral, hereditary, autoimmune or drug origin as the cause of cytolytic, cholestatic and mesenchymal also the results of ultrasonographic (USG) examination of the liver. The degree of hepatic steatosis and its nature were determined using a ratified kit "SteatoTest", "ASH" and "NASHTest" (BioPredictive, France) in the laboratory Synevo. The stage of liver fibrosis was determined by using a set of markers for quantitative biochemical evaluation of fibrosis "FibroTest" (BioPredictive, France) in the laboratory Synevo.

Diagnosis of type 2 diabetes was performed in accordance with the unified clinical protocol approved by the Order of the Ministry of Health of Ukraine № 1118 of 21.12.2012. Diagnosis and treatment of CKD was carried out according to the recommendations of clinical guidelines SI "Institute of Nephrology NAMS of Ukraine" (2012). Calculation of the glomerular filtration rate (GFR) was performed using a GFR calculator of the Institute of Nephrology of the National Academy of Medical Sciences of Ukraine on the average of three calculated indicators: creatinine clearance according to the Cockcroft-Golt formula, MDRD and CKD EPI [9]. Determination of the stages of CKD was carried out according to the classification of C.E. Mogensen (1983) $[12,13]$.

The state of carbohydrate metabolism was determined by the level of fasting blood glucose and blood glucose 2 hours after a meal (postprandial ( $\mathrm{p} / \mathrm{p}$ ) glucose) by glucose oxidase method; fasting insulin content (DRG System) by enzyme-linked immunosorbent assay (ELISA); content of glycosylated hemoglobin (HbA1c) in the blood using standard reagent kits "Simko Ltd" (Lviv). The degree of IR was determined by the value of the body mass index (BMI), HOMA-IR index and tissue sensitivity index to insulin (S) (DR Matthews et al.) [17], which was calculated using the HOMA2 Calculator Version 2.2 Diabetes Trials Unit University of Oxford (United Kingdom).

Statistical analysis of the results was performed according to the type of study and the types of numerical data that were obtained. The normality of the distribution was checked using Liliefors, Shapiro-Wilk tests and the method of direct visual evaluation of histograms of the distribution of eigenvalues. Quantitative values that had a normal distribution are presented as mean (M) \pm standard deviation (S). Discrete values are presented in the form of absolute and relative frequencies (percentage of observations to the total number of subjects). For comparisons of data that had a normal distribution, we used parametric tests with the assessment of Student's ttest, Fisher's F-test. In the case of an abnormal distribution, the calculation of the Mann-Whitney rank U-test was used, and for multiple comparison, the Wilcoxon T-test was used (in the case of the study of dependent groups). Pearson correlation analysis in the parametric distribution and Spearman's rank correlation coefficient in the case of the distribution of indicators that were significantly different from the normal one were used to assess the degree of dependence between the variables. For statistical and graphical analysis of the obtained results we used software packages Statistica for Windows version 8.0 (Stat Soft inc., USA), Microsoft Excel 2007 (Microsoft, USA).

Research results and their discussion. Analysis of renal function in patients with NASH with diabetes without DKD (1 group) indicates a normal level of albumin in the blood, normal GFR and albuminuria (Table 2). At the same time, in patients with NASH, diabetes mellitus and DKD I-II. (Group 2) found a

Table 1

Distribution of examined patients with non-alcoholic fatty liver disease and type 2 diabetes mellitus depending on the presence of DKD and stage of DKD $(n, \%)$

\begin{tabular}{|c|c|c|c|c|c|c|c|c|c|c|}
\hline \multirow{3}{*}{$\begin{array}{l}\text { Examined } \\
\text { patients }\end{array}$} & \multirow{2}{*}{\multicolumn{2}{|c|}{$\begin{array}{l}\text { Number of } \\
\text { examined } \\
\text { patients }\end{array}$}} & \multicolumn{8}{|c|}{ Comorbidity options, stages DKD } \\
\hline & & & \multicolumn{2}{|c|}{$\begin{array}{l}\text { NASH with } \\
\text { DM2 without } \\
\text { DKD }\end{array}$} & \multicolumn{2}{|c|}{$\begin{array}{l}\text { NASH with } \\
\text { DM2 with DKD } \\
\text { I-II stages }\end{array}$} & \multicolumn{2}{|c|}{$\begin{array}{l}\text { NASH with DM2 } \\
\text { with DKD III stage }\end{array}$} & \multicolumn{2}{|c|}{$\begin{array}{c}\text { NASH with } \\
\text { DM2 with DKD } \\
\text { IV stage }\end{array}$} \\
\hline & $\mathrm{n}$ & $\%$ & $\mathrm{~N}$ & $\%$ & $\mathrm{n}$ & $\%$ & $\mathrm{n}$ & $\%$ & $\mathrm{n}$ & $\%$ \\
\hline NASH & 108 & 100 & 28 & 25,9 & 27 & 25,0 & 28 & 25,9 & 25 & 23,1 \\
\hline
\end{tabular}


Original research

probable decrease in the content of albumin in the blood by $9.0 \%$ ( $p<0.05)$, GFR and the content of albumin in the urine, on the contrary, probably increased 1.5 times ( $\mathrm{p}<0.05$ ) compared with PHP (Table 2), which indicates the phenomenon of hyperfiltration and inherent in the initial stage of DKD. In patients with NASH, diabetes mellitus and DKD III. (Group 3) found a probable decrease in blood albumin by 1.2 times $(p<0.05)$, GFR and albuminuria were significantly increased by 1.4 times and 11.7 times ( $p<0.05)$, respectively. compared with the indicator in PHP (table 2).

In patients with NASH, diabetes mellitus and DKD IV. (Group 4) found a significant decrease in the content of albumin in the blood by 1.4 times $(p<0.05$ ), the content of albumin in the blood was probably increased by 30.2 times $(\mathrm{p}<0.05)$ compared with the PHP (Table 2 ), and the GFR index - on the contrary was significantly reduced - 1.7 times $(p<0.05)$, which indicates the progression of CKD and DKD.

The results of glycemia, insulinemia and IR indices in patients with NASH with diabetes mellitus2 are shown in table 3 . The analysis of studies showed that patients of all groups found a significant probable increase in fasting glycemia: in group 1 - 1.6 times, in 2 - in 1.8 times, in group $3-2.5$ times and in group $4-2.7$ times $(p<0.05)$ compared to the indicator in PHP. Examination of the insulin content in the blood on an empty stomach revealed a probable hyperinsulinemia, which in patients of the 1st group exceeded the indicator in the group of PHP in 1.9 times, in patients of the 2 nd group - in 2.4 times, in the 3 rd group - in 2.9 times and the 4th group 3.3 times $(\mathrm{p}<0.05)$ (table 3$)$.

The above processes resulted in significant changes in IR and peripheral tissue sensitivity to insulin.

In particular, the violation of peripheral tissue sensitivity to insulin in patients with NASH and diabetes mellitus indicates a probable increase in the HOMA IR index (respectively in groups 1, 2, 3 and $4-2.2$ times, $2.7,3.5$ and 4.0 times $(\mathrm{p}<0,05)$ ), as well as an adequate decrease in $S(p<0,05)$ with a significant difference between 1, 2 and 3, 4 groups ( $p<0,05$ ) (Table 3 ). At the same time, there was no difference between the indicator of another marker of IR - BMI in patients of different groups ( $p>0.05$ ), but the indicator in all groups of patients exceeded the data in PHP by 1.3 times $(\mathrm{p}<0.05)$ (table 3).

The consequence of chronic fasting and postprandial hyperglycemia was an increase in blood glycosylated hemoglobin in these observation groups (respectively in groups 1, 2, 3 and $4-1.6$ times, 1.9, 2.4 and 2.5 times (p $<0.05)$ ) with a probable difference between 1, 2 and 3, 4 groups ( $\mathrm{p}<0,05)$.

Analysis of glucose and insulin homeostasis in relation to markers of liver damage, indicators of functional status of the liver and kidneys in patients with NASH with diabetes mellitus2 and DKD IV. indicates that postprandial and supracardiac hyperglycemia and insulinemia, as well as the degree of IR in a weak to medium strength relationship increase with increasing intensity of cytolysis, cholestasis, mesenchymal inflammation, and are factors of mutual burden of NASH and DM2 with DKD due to induction of induction markers of HCN (albumin content in the blood - a weak negative link), contribute to the development of hepatic steatosis (strong correlation with the steato test), renal dysfunction (weak-medium strength with blood creatinine, albuminuria and moderate negative negative GFR) ( $\mathrm{p}<0.05)$ (table 4).

Thus, the most significant metabolic prerequisites for the development of NASH on the background of diabetes mellitus are probable fasting and postprandial hyperglycemia, hyperinsulinemia, increased hemoglobin glycosylation, tissue IR. One of the risk factors for the progression of NASH and the background of diabetes mellitus is the presence of DKD, as impaired carbohydrate metabolism and the degree of IR in these conditions are more significant compared to the course of $\mathrm{NASH}$ in the absence of DKD $(\mathrm{p}<0.05)$. The progression

Table 2

Indicators of the functional state of the kidneys in patients with NASH, type 2 diabetes depending on the presence of DKD and its stage

\begin{tabular}{|c|c|c|c|c|c|}
\hline \multirow{2}{*}{$\begin{array}{c}\text { Indicators of } \\
\text { the unit of } \\
\text { measurement }\end{array}$} & $\begin{array}{c}\text { PHP } \\
(\mathrm{n}=30)\end{array}$ & $\begin{array}{c}\text { NASH with DM2 } \\
\text { without DKD } \\
(\mathrm{n}=28)\end{array}$ & $\begin{array}{c}\text { NASH with DM2 } \\
\text { with DKD I-II stages } \\
(\mathrm{n}=27)\end{array}$ & $\begin{array}{c}\text { NASH with } \\
\text { DM2 with DKD } \\
\text { III stage (n=28) }\end{array}$ & $\begin{array}{c}\text { NASH with } \\
\text { DM2 with DKD } \\
\text { IV stage } \\
(\mathrm{n}=25)\end{array}$ \\
\hline $\begin{array}{c}\text { Blood } \\
\text { albumins, g/l }\end{array}$ & $40,9 \pm 1,3$ & $39,1 \pm 0,8$ & $37,2 \pm 0,9 *$ & $\begin{array}{c}32,3 \pm 0,8 \\
* / * * / * * *\end{array}$ & $\begin{array}{c}28,2 \pm 0,9 \\
* / * * / * * * / \#\end{array}$ \\
\hline $\begin{array}{c}\text { GFR, ml / min / } \\
\text { 1.72m2 }\end{array}$ & $95,3 \pm 1,6$ & $91,5 \pm 2,1$ & $145,0 \pm 2,0 * / * *$ & $\begin{array}{c}134,6 \pm 2,3 \\
* / * * / * * *\end{array}$ & $\begin{array}{c}57,0 \pm 1,2 \\
* / * * / * * * / \#\end{array}$ \\
\hline $\begin{array}{c}\text { Urine albumin } \\
\text { mg / day }\end{array}$ & $18,4 \pm 0,7$ & $20,3 \pm 0,5$ & $28,4 \pm 1,6 * / * *$ & $\begin{array}{c}210,5 \pm 8,7 \\
* / * * / * * *\end{array}$ & $\begin{array}{c}543,1 \pm 2 \pm 24,9 \\
* / * * / * * * / \#\end{array}$ \\
\hline
\end{tabular}

Note: $*$ - the difference is probable in comparison with the indicator in almost healthy individuals $(\mathrm{p}<0,05)$; ** the difference is probable in comparison with the indicator in patients with NASH with diabetes mellitus2 (p <0.05); $* * *$ - the difference is significant in comparison with the rate in patients with NASH with diabetes mellitus, DKD III ( $<<0,05)$; \# - the difference is significant in comparison with the indicator in patients with NASH with diabetes mellitus2, DKD III $(\mathrm{p}<0,05)$. 
Indicators of blood glucose and blood insulin, glycosylated hemoglobin, IR indices in patients with NASH, type 2 diabetes mellitus depending on the presence of DKD and the stage of DKD $(M \pm m)$

\begin{tabular}{|c|c|c|c|c|c|}
\hline \multirow[b]{2}{*}{$\begin{array}{l}\text { Indicators of } \\
\text { the unit of } \\
\text { measurement }\end{array}$} & \multirow[b]{2}{*}{$\begin{array}{c}\text { PHP } \\
(n=30)\end{array}$} & \multicolumn{4}{|c|}{ Groups of examined patients } \\
\hline & & $\begin{array}{c}\text { NASH with DM2 } \\
\text { without DKD } \\
\quad(n=28)\end{array}$ & $\begin{array}{c}\text { NASH with DM2 } \\
\text { with DKD I-II } \\
\text { stages } \\
(\mathrm{n}=27)\end{array}$ & $\begin{array}{c}\text { NASH with } \\
\text { DM2 with DKD } \\
\text { III stage }(n=28)\end{array}$ & $\begin{array}{c}\text { NASH with } \\
\text { DM2 with DKD } \\
\text { IV stage } \\
(\mathrm{n}=25)\end{array}$ \\
\hline $\begin{array}{c}\text { Fasting } \\
\text { glucose, mmol / } \\
1\end{array}$ & $4,23 \pm 0,27$ & $6,82 \pm 0,31 *$ & $7,78 \pm 0,24 * / * *$ & $\begin{array}{c}10,52 \pm 0,27 \\
* / * * / * * *\end{array}$ & $\begin{array}{c}11,58 \pm 0,44 \\
* / * * / * * * / \#\end{array}$ \\
\hline $\begin{array}{c}\text { Insulin on an } \\
\text { empty stomach, } \\
\text { mkOD / } 1\end{array}$ & $9,92 \pm 2,17$ & $19,35 \pm 2,15 *$ & $23,50 \pm 1,21 *$ & $\begin{array}{c}28,97 \pm 1,53 \\
* / * * / * * *\end{array}$ & $\begin{array}{c}32,39 \pm 1,15 \\
* / * * / * * *\end{array}$ \\
\hline $\mathrm{Hb} \mathrm{A} 1 \mathrm{C}, \%$ & $4,07 \pm 0,23$ & $6,70 \pm 0,31 *$ & $7,63 \pm 0,43 *$ & $\begin{array}{c}9,95 \pm 0,52 \\
* / * * / * * *\end{array}$ & $\begin{array}{c}10,37 \pm 0,47 \\
* / * * / * * *\end{array}$ \\
\hline $\begin{array}{l}\text { Index HOMA- } \\
\text { IR2 }\end{array}$ & $1,23 \pm 0,26$ & $2,65 \pm 0,35 *$ & $3,28 \pm 0,24 *$ & $\begin{array}{c}4,26 \pm 0,21 \\
* / * * / * * *\end{array}$ & $\begin{array}{l}4,98 \pm 0,20 \\
* / * * / * * *\end{array}$ \\
\hline $\mathrm{S}, \%$ & $81,61 \pm 7,24$ & $37,82 \pm 3,27 *$ & $30,55 \pm 3,12 *$ & $23,50 \pm 2,87 * / * *$ & $\begin{array}{c}20,11 \pm 2,18 \\
* / * * / * * *\end{array}$ \\
\hline $\begin{array}{c}\text { Body mass } \\
\text { index, } \mathrm{kg} / \mathrm{m} 2\end{array}$ & $23,08 \pm 1,65$ & $29,21 \pm 1,19 *$ & $30,42 \pm 1,33 *$ & $30,79 \pm 1,49 *$ & $29,88 \pm 1,45 *$ \\
\hline \multicolumn{6}{|c|}{$\begin{array}{l}\text { Note: } * \text { - the difference is probable in comparison with the indicator in almost healthy individuals }(\mathrm{p}<0,05) ; * *- \\
\text { the difference is probable in comparison with the indicator in patients with NASH with diabetes mellitus } 2 \text { (p } \\
<0.05) \text {; *** - the difference is significant in comparison with the rate in patients with NASH with diabetes mellitus, } \\
\text { DKD I-II }(\mathrm{p}<0,05) \text {; \# - the difference is significant in comparison with the indicator in patients with NASH with } \\
\text { diabetes mellitus2, DKD III }(\mathrm{p}<0,05) \text {. }\end{array}$} \\
\hline
\end{tabular}

Matrix of correlations of markers of damage and functional parameters of the liver, kidneys with indicators of glucose homeostasis and insulin content in the blood, indices of insulin resistance in patients with NASH

\begin{tabular}{|c|c|c|c|c|c|c|}
\hline Indicator & $\begin{array}{l}\text { Fasting } \\
\text { glucose }\end{array}$ & $\begin{array}{l}\text { Postprandial } \\
\text { glucose }\end{array}$ & Insulin & HOMA IR & BMI & $\mathrm{HbA}_{1 \mathrm{C}}$ \\
\hline ALAT & $0,50 *$ & $0,55^{*}$ & 0,29 & $0,57 *$ & 0,22 & $0,53 *$ \\
\hline Alkaline phosphatase & $0,39 *$ & $0,41 *$ & 0,15 & $0,42 *$ & 0,17 & $0,36^{*}$ \\
\hline Thymol test & $0,42 *$ & $0,47 *$ & 0,26 & $0,53 *$ & 0,28 & $0,55^{*}$ \\
\hline Steatotest & $0,64 *$ & $0,71 *$ & $0,34 *$ & $0,74 *$ & $0,59 *$ & $0,69 *$ \\
\hline Albumins & $-0,37 *$ & $-0,42 *$ & $-0,33 *$ & $-0,49 *$ & $-0,32 *$ & $-0,46^{*}$ \\
\hline Blood creatinine & $0,56^{*}$ & $0,63 *$ & $0,44 *$ & $0,63 *$ & $0,43 *$ & $0,57 *$ \\
\hline GFR & $-0,51 *$ & $-0,57 *$ & $-0,41^{*}$ & $-0,61 *$ & $-0,47^{*}$ & $-0,51$ \\
\hline Albuminuria & $0,48 *$ & $0,52 *$ & $0,35^{*}$ & $0,58 *$ & $0,38^{*}$ & $0,48 *$ \\
\hline
\end{tabular}

of DKD from stage I to IV on the background of DM2 in comorbidity with NASH depends on the degree of supracardiac, postprandial hyperglycemia and the degree of IR (HOMA IR) ( $\mathrm{p}<0,05)$.

\section{Conclusions}

1. Metabolic prerequisites for the development of NASH on the background of diabetes mellitus are probable fasting and postprandial hyperglycemia (1.6 times, $\mathrm{p}<0.05)$, hyperinsulinemia (1.9 times, $\mathrm{p}<0.05)$, an increase in the degree of glycosylation of hemoglobin (1 , 6 times, $\mathrm{p}<0.05$ ), tissue IR (increase in HOMA 2.2 times, $\mathrm{p}<0.05)$ compared with healthy individuals.

2. Disorders of glucose homeostasis due to IR is one of the probable risk factors for the progression of NASH and diabetes mellitus in the presence of DHN I-IV centuries, as carbohydrate metabolism disorders (fasting hyperglycemia - 2.3 times, $\mathrm{p}<0.05$, insulin content -2.9 times, $\mathrm{p}<0.05$, glycosylated hemoglobin -2.3 times, $\mathrm{p}$ $<0.05$ ) and the degree of IR (increase in HOMA 3.4 times, $\mathrm{p}<0.05)$ ) under these conditions is more significant in comparison with the course of NASH with diabetes mellitus in the absence of DKD ( $p<0.05)$.

3. Indicators of postprandial and supracardial glycemia and insulinemia, as well as the degree of IR in patients with NASH and diabetes mellitus2 with DKD IV. in weak-medium strength of the relationship affect 
Original research

the increase in the intensity of cytolysis, cholestasis, mesenchymal inflammation, and are factors of mutual burden of NASH and CM2 with DKD due to induction of hepatocyte damage, progression of $\mathrm{HCN}$ (blood albumin content - weak negative connection), contribute development of hepatic steatosis (strong correlation with steato-test index), renal dysfunction (positive weakmedium strength with blood creatinine, albuminuria and moderate strength negative with GFR) $(\mathrm{p}<0.05)$.

4. The progression of DKD from stage I-II to IV on the background of diabetes mellitus in combination with NASH (in weak-medium strength interdependence) depends on the degree of supracardiac, postprandial hyperglycemia and the degree of IR (HOMA IR) (p $<0.05$ ).

The prospect of further research in this area is the search for drugs for adequate correction of carbohydrate metabolism, reducing the degree of IR and eliminating the manifestations of liver damage in the treatment of NASH on the background of diabetes mellitus 2 depending on the stage of $\mathrm{HCN}$.

\section{Список літератури}

1. Хухліна ОC, Антонів АА. Клінічний перебіг неалкогольного стеатогепатиту за коморбідності 3 хронічною хворобою нирок I-III стадії. Гепатологія. 2017;4:37-48.

2. Хухліна ОC, Антонів АА. Неалкогольна жирова хвороба печінки та хронічна хвороба нирок: патогенез взаємообтяження, особливості клініки, діагностики, прогнозування перебігу. Чернівці; 2019. 192 с.

3. American Diabetes Association A2. Classification and Diagnosis of Diabetes: Standards of Medical Care in Diabetes2018. Diabetes Care. 2018;41(1):13-27. DOI: $10.2337 / \mathrm{dc} 18-$ S002.

4. Bermejo S, Soler MJ, Gimeno J, Barriosa C, Rodrígueza E, Mojalet $\mathrm{S}$, et al. Predictive factors for non-diabetic nephropathy in diabetic patients. The utility of renal biopsy. Nefrologia. 2016;36(5):465-82.

5. Панькив ВИ. Сахарный диабет 2-го типа и неалкогольная жировая болезнь печени. Эффекты метформина. Міжнародний ендокринологічний журнал. 2013;5:55-63.

6. Bril F, Lomonaco R, Orsak B, Ortiz-Lopes C, Webb A, Tio F, et al. Relationship between disease severity, hyperinsulinemia, and impaired insulin clearance in patients with nonalcoholic steatohepatitis. Hepatology. 2014;59(6):2178-87. DOI: 10.1002/hep.26988.

7. Mantovani A, Byrne CD, Bonora E, Targher G. Nonalcoholic Fatty Liver Disease and Risk of Incident Type 2 Diabetes: A Meta-analysis. Diabetes Care. 2018;41(2):372-82. DOI: $10.2337 / \mathrm{dc} 17-1902$.

8. Gastaldelli A. Insulin resistance and reduced metabolic flexibility: cause or consequence of NAFLD? Clin Sci. 2017;131(2):2701-04. DOI: 10.1042/CS20170987.

9. Khukhlina OS, Antoniv AA, Dudka IV, Dudka TV, Mandryk OYe. The state of blood lipid spectrum and the indicators of insulin resistance in patients with non-alcoholic steatohepatitis with obesity and hypertensive disease. Світ медицини та біології. 2018;2:85-8.

10. Rosso C, Mezzabotta L, Gaggini M, Salomone F, Gambino R, Marengo A, et al. Peripheral insulin resistance predicts liver damage in nondiabetic subjects with nonalcoholic fatty liver disease. Hepatology. 2016;63(1):107-16. DOI: 10.1002/hep.28287.

11. Gaggini M, Morelli M, Buzzigoli E, DeFronzo RA, Bugianesi E, Gastaldelli A, et al. Non-alcoholic fatty liver disease (NAFLD) and its connection with insulin resistance, dyslipidemia, atherosclerosis and coronary heart disease. Nutrients. 2013;5(5):1544-60. DOI: 10.3390/nu5051544.

12. Майданник ВГ, Бурлака $Є А$. Стан метаболічногіпоксичних порушень при діабетичний нефропатії у дітей. Експериментальна та клінічна фізіологія і біохімія. 2015;72(4):47-55.

13. Шуляренко ЛВ. Хронічна діабетична хвороба нирок: сучасний погляд на проблему. Ендокринологія. 2013;18(1):73-82.

14. Tuttle KR, Bakris GL, Bilous RW, Chiang JL, de Boer $\mathrm{IH}$, Goldstein-Fuchs J, et al. Diabetic kidney disease: A report from an ADA Consensus Conference. Am J Kidney Dis. 2014;64(4):510-33. doi: 10.1053/j.ajkd.2014.08.001.

15. Doshi SM, Friedman AN. Diagnosis and Management of Type 2 Diabetic Kidney Disease. Clin J Am Soc Nephrol. 2017;12(8):1366-73.

https://doi.org/10.2215/CJN.11111016.

16. Gastaldelli A, Cusi K. From NASH to diabetes and from diabetes to NASH: Mechanisms and treatment options. JHEP Rep. 2019;1(4):312-28. DOI: 10.1016/j.jhepr.2019. 07.002 .

17. Isokuortti E, Zhou Y, Peltonen M, Bugianesi E, Clement K, Bonnefont-Rousselot D, et al. Use of HOMA-IR to diagnose non-alcoholic fatty liver disease: a population-based and inter-laboratory study. Diabetologia. 2017;60:1873-82. DOI: $10.1007 / \mathrm{s} 00125-017-4340-1$.

\section{References}

1. Khukhlina OS, Antoniv AA. Klinichnyi perebih nealkohol'noho steatohepatytu za komorbidnosti z khronichnoiu khvoroboiu nyrok I-III stadii [Clinical course of non-alcoholic steatohepatitis with comorbidity with chronic kidney disease stage I-III]. Hepatolohiia. 2017;4:37-48. (in Ukrainian).

2. Khukhlina OS, Antoniv AA. Nealkoholna zhyrova khvoroba pechinky ta khronichna khvoroba nyrok: patohenez vzaiemoobtiazhennia, osoblyvosti kliniky, diahnostyky, prohnozuvannia perebihu [Non-alcoholic fatty liver disease and chronic kidney disease: pathogenesis of mutual burden, features of the clinic, diagnosis, prognosis]. Chernivtsi; 2019. 192 p. (in Ukrainian).

3. American Diabetes Association A2. Classification and Diagnosis of Diabetes: Standards of Medical Care in Diabetes2018. Diabetes Care. 2018;41(1):13-27. DOI: $10.2337 / \mathrm{dc} 18-$ S002.

4. Bermejo S, Soler MJ, Gimeno J, Barriosa C, Rodrígueza E, Mojalet S, et al. Predictive factors for non-diabetic nephropathy in diabetic patients. The utility of renal biopsy. Nefrologia. 2016;36(5):465-82.

5. Pan'kiv VI. Sakharnyy diabet 2-go tipa i nealkogol'naya zhirovaya bolezn' pecheni. Effekty metformina [Type 2 diabetes mellitus and non-alcoholic fatty liver disease. Effects of metformin]. Mizhnarodnyi endokrynolohichnyi zhurnal. 2013;5:55-63. (in Russian).

6. Bril F, Lomonaco R, Orsak B, Ortiz-Lopes C, Webb A, Tio F, et al. Relationship between disease severity, hyperinsulinemia, and impaired insulin clearance in patients with nonalcoholic steatohepatitis. Hepatology. 2014;59(6):2178-87. DOI: 10.1002/hep.26988.

7. Mantovani A, Byrne CD, Bonora E, Targher G. Nonalcoholic Fatty Liver Disease and Risk of Incident Type 2 Diabetes: A Meta-analysis. Diabetes Care. 2018;41(2):372-82. DOI: $10.2337 / \mathrm{dc} 17-1902$. 


\section{Оригінальні дослідження}

8. Gastaldelli A. Insulin resistance and reduced metabolic flexibility: cause or consequence of NAFLD? Clin Sci. 2017;131(2):2701-04. DOI: 10.1042/CS20170987.

9. Khukhlina OS, Antoniv AA, Dudka IV, Dudka TV, Mandryk OYe. The state of blood lipid spectrum and the indicators of insulin resistance in patients with non-alcoholic steatohepatitis with obesity and hypertensive disease. Svit medytsyny ta biolohii. 2018;2:85-8.

10. Rosso C, Mezzabotta L, Gaggini M, Salomone F, Gambino R, Marengo A, et al. Peripheral insulin resistance predicts liver damage in nondiabetic subjects with nonalcoholic fatty liver disease. Hepatology. 2016;63(1):107-16. DOI: 10.1002/hep.28287.

11. Gaggini M, Morelli M, Buzzigoli E, DeFronzo RA, Bugianesi E, Gastaldelli A, et al. Non-alcoholic fatty liver disease (NAFLD) and its connection with insulin resistance, dyslipidemia, atherosclerosis and coronary heart disease. Nutrients. 2013;5(5):1544-60. DOI: 10.3390/nu5051544.

12. Maidannyk VH, Burlaka YeA. Stan metabolichnohipoksychnykh porushen' pry diabetychnyi nefropatii u ditei [The state of metabolic-hypoxic disorders in diabetic nephropathy in children]. Eksperymental'na ta klinichna fiziolohiia i biokhimiia. 2015;72(4):47-55. (in Ukrainian).

13. Shuliarenko LV. Khronichna diabetychna khvoroba nyrok: suchasnyi pohliad na problemu [Chronic diabetic kidney disease: a modern view of the problem]. Endokrynolohiia. 2013;18(1):73-82. (in Ukrainian).

14. Tuttle KR, Bakris GL, Bilous RW, Chiang JL, de Boer IH, Goldstein-Fuchs J, et al. Diabetic kidney disease: A report from an ADA Consensus Conference. Am J Kidney Dis. 2014;64(4):510-33. DOI: 10.1053/j.ajkd.2014.08.001.

15. Doshi SM, Friedman AN. Diagnosis and Management of Type 2 Diabetic Kidney Disease. Clin J Am Soc Nephrol. 2017;12(8):1366-73. DOI: https://doi.org/10.2215/ CJN. 11111016.

16. Gastaldelli A, Cusi K. From NASH to diabetes and from diabetes to NASH: Mechanisms and treatment options. JHEP Rep. 2019;1(4):312-28. DOI: 10.1016/j.jhepr.2019.07.002

17. Isokuortti E, Zhou Y, Peltonen M, Bugianesi E, Clement K, Bonnefont-Rousselot D, et al. Use of HOMA-IR to diagnose non-alcoholic fatty liver disease: a population-based and inter-laboratory study. Diabetologia. 2017;60:1873-82. DOI: $10.1007 / \mathrm{s} 00125-017-4340-1$.

\section{Відомості про авторів}

Хухліна О.С. - д-р. мед. наук, професор, завідувач кафедри внутрішньої медицини, клінічної фармакології та професійних хвороб, ВДНЗ України «Буковинський державний медичний університет», м. Чернівці, Україна.

Коцюбійчук 3.Я. - асистент кафедри внутрішньої медицини, клінічної фармакології та професійних хвороб, ВДНЗ України «Буковинський державний медичний університет»; лікар-терапевт, Обласне комунальне некомерційне підприємство «Чернівецька лікарня швидкої медичної допомоги», м. Чернівці, Україна.

\section{Сведения об авторах}

Хухлина О.С. - д-р. мед. наук, профессор, зав. каф. внутренней медицины, клинической фармакологии и профессиональных болезней, ВГУЗ Украины «Буковинский государственный медицинский университет», г.Черновцы, Украина.

Коцюбийчук 3.Я. - ассистент каф. внутренней медицины, клинической фармакологии и профессиональных болезней, ВГУЗ Украины «Буковинский государственный медицинский университет»; врач-терапевт, Обласное коммунальное некоммерческое предприятие «Черновицкая больница скорой медицинской помощи», г. Черновцы, Украина.

\section{Information about the authors}

Khukhlina O.S. - MD, PhD, DSci, Professor, Head of the Department of Internal Medicine, Clinical Pharmacology and Occupational Diseases, Higher State Educational Institution of Ukraine "Bukovinian State Medical University", Chernivtsi, Ukraine.

Kotsiubiichuk Z.Ya. - assistant, Department of Internal Medicine, Clinical Pharmacology and Occupational Diseases, Higher State Educational Institution of Ukraine "Bukovinian State Medical University"; Therapist, Regional Municipal Non-Profit Enterprise "Chernivtsi Emergency Hospital", Chernivtsi, Ukraine 